\title{
God seen through the eyes of Savatie Baştovoi
}

\section{Paula-Andreea Onofrei}

Savatie Baștovoi, Dumnezeu povestit pe inţelesul unei femei / God Narrated to be Comprehended by a Woman Editura Cathisma, București, 2017.

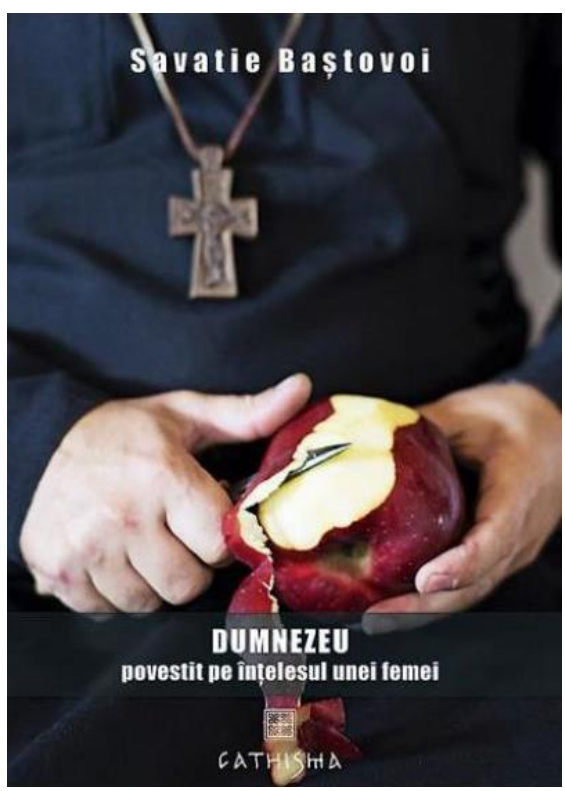

First and foremost, why have we chosen this book having such an intriguingly well-targeted audience, being addressed to women, why it cannot be regarded as a book which has been written for the large audience, for each and every reader interested in discovering God? In the introductory part, the author himself underlines that "the title does not hide any challenge, but it reveals a reality which is as simple as it can be: the book is called God Narrated to be Comprehended by a Woman because it offers my answers about God offered to a concrete woman, the journalist Doina Popa from Vip Magazin".

Secondly, regarding the structure of the book, the author has launched the coordinates of this volume by asking the journalist to send his no more than 33 questions (of course, related to the symbolism of the age of Jesus Christ when He was crucified) that Savatie Baştovoi would answer taking full responsibility for his words, integrating Biblical and patristic sources in an accessible manner.

Thirdly, as far as the writing style is concerned, we believe that the author has applied the principle multum in parvo, each answer has exactly the

\footnotetext{
${ }^{1}$ SavatieBaştovoi, Dumnezeupovestitpeînţelesuluneifemei [God Narrated to be Comprehended by a Woman], Cathisma Publishing House, Bucharest, 2017, page 5, my translation.
} 
number of words which are considered enough to provide food for thought, according to Baştovoi's words ${ }^{2}$.

Furthermore, it is of outmost importance to mention that this volume has two parts: the first is a collection of answers to the above-mentioned 33 questions, while the second contains Baştovoi's notes from Oricova, the things that he wrote down while he was building the church, as a sign of the fact that the beginning of this book was is Oricova. These poetic reflections about God and the world that surrounds us are "very much appropriate as a desert after the somehow sober dinner had in the first part of the book"3.

In order to stir one's interest, I am going to mention here the 33 questions that Doina Popa has launched, according to my translation:

1.When I was little, I used to spend hours watching the sky and imagining God sitting on clouds, looking at me in His turn. I sometimes moved like a doll on a scene, at that time, I only heard about theatrical performances from books, and I imagined that I am driven from above. I believe many children have these moments. Why do we picture God in this way? How is God seen in childhood?

2. Why would God cry today?

3. Regarding tears, I often ask myself where God is when my mother hurts and I know that she doesn't deserve to suffer... These questions, in time, have extended over other dear people. Does God give us suffering? Why does He do it?

4. Why should humbleness exist? Is dignity something we should condemn? On the one hand, God is Almighty, on the other hand, He tells us about being humble. If humility is something good, is God humble?

5. If God did everything right, why does sin exist? Who decides which thing is a sin or not?

6. Why are some sins forgiven, while others not, because it is said that the sin against the Holy Spirit is not to be forgiven? Who decides and who can know if a sin was forgiven?

7. How do women repent and how do men do it? In the Gospel, it is revealed to us that the woman who sinned washed the feet of Christ with her tears. Do men cry, also? Do men and women see sins in the same way?

8. Why does the Church not accept women as priests?

9. Is it necessary to know when and how to pray or you can pray the way you want to?

10. I am a mother...is the prayer of a mother stronger than anything?

11. I believe that God talks to me through randomly met people...most often, they appear in crowded buses, they can be old, children, women with serene

\footnotetext{
${ }^{2}$ Ibidem, page 6 .

${ }^{3}$ Idem, page 7 , my translation.
} 
eyes...who make me talk to them, sometimes they make me cry, they thrill me, they don't let me forget them. Is it like this? Are they truly random?

12. What does God say about being merciful and offering charity? Are there situations in which if you offer, you can do harm? Are there limits? Why is the Church accused of not offering enough charity?

13. Is it a sin to wash the laundry on Sunday and when it is a celebration day? What should I do if Saturday is a celebration day and Sunday is Sunday, when I wash the laundry? What other things are forbidden when it's Sunday or a religious celebration?

14. Can I confess my sins, directly to God? Often, words do not truly express what we feel or we cannot talk about the things that are a burden for our soul... Why must I confess to a priest and I cannot do it directly to God?

15. Why has God created flowers?

16. If God loves us so much, why does He enjoy seeing us on bedded knees?

17. What is the mission of the Church between God and I? Why must I pray inside the church, if I can also do it at home or in any other place?

18. Why are some people born being very beautiful from a physical point of view, while others are ugly? Does this have any connection to God's blessings or curses? Is beauty a blessing and ugliness a curse? Today, more and more people, especially women, go to the doctors to shape their physical appearance, because this type of intervention has become very much accessible. Is it a sin to have beauty surgeries?

19. When does pleasure become a sin?

20. Does the devil exist? What are charms, curses, bindings and undoings that make so many people be afraid? We have heard about priests that make undoing payers, I wonder...are exorcism prayers made by the Church still available today? To what extent a curse or a charm made by someone can influence our faith? Should we be afraid of charms or not?

21. God is the father of nature, why doesn't He stop it in case of calamity, when thousands and dozens of thousands of people are caught by the same "wave"? Or why has God created such enormous forces, that can destroy a lot?

22. People punish people, they judge them, they put them in jail, they decide how much they should stay there. How does God see this?

23. Why do priests wear black clothes?

24. Why is it in our human nature to always want what one does not have and to compare oneself with the others? How does envy manifest itself at men and at women?

25. Why in the Bible, genealogical series contain only men names? Isn't this a way of diminishing the importance of women?

26. Is it good to believe in signs? A lot of television and radio channels transmit the horoscope on a daily basis and a lot of people believe in astral predictions. There are even pieces of advice regarding sign matching and you 
can often hear things like "what can you do about it, this is how lions are" or "this is how cancers are" or "he's a bull and he will never forgive you". Do signs influence our destiny in any way? What does the Bible say about astrology, taking into account the fact that Christ's birth was foretold by a star and that the Magi were the first that came to worship Baby Jesus? Can we say that the event with the appearance of the star when Jesus was born and Magi's worshipping are a sign that God approves astrology?

27. If we are all born with the original sin, it means that we do not have any chance to be the way God wants us to be. How is it possible to inherit a sin that someone else committed and why are we guilty for what Adam did in Heaven? Or does Christening erase this original sin?

28. The fact that God knows our life and deeds in advance means that everything is predestined? Or are there predestined things, decided by God to happen and others which depend on our choices? Why do we say that a human being has a specific calling, a vocation? If destiny exists, which part of our life is already established?

29. What has Jesus written on the sand?

30. How is the Kingdom of God?

31.Does God show His face?

32.Does God want to be asked questions?

33.After 2000 years, the world hasn't changed and doesn't seem to ever change. According to Christ's pieces of advice, the world is a utopia. Why has God given some commandments which can't change the world? Is this a failure of God?

In conclusion, God Narrated to be Comprehended by a Woman is not a book about women, but it is entirely dedicated to God, a short, but meaningful presentation of what Our Saviour is, from a healthy Orthodox perspective, being written in a concise style, always bringing valid arguments which are well-chosen, having their roots in the large general knowledge of the author. 